\title{
RESPON TURKI TERHADAP TINDAKAN DISKRIMINATIF PEMERINTAH CINA KEPADA ETNIS UIGHUR DI XINJIANG (2009-2015)
}

\author{
Zulkarnain dan Syifa Nur Ghonimah \\ Universitas Nasional (UNAS) Jakarta, Indonesia \\ E-mail: zulkarnainunas@gmail.com dan syifnrg@gmail.com
}

\section{Abstract}

This study aims to explain Turkey's response to discriminatory acts committed by the Chinese government against ethnic Uighurs in Xinjiang in 2009 - 2015. Discriminatory actions occur due to cultural complexity in a country, one of which is China, which has committed discriminatory actions against Uighurs. To find out the response given by Turkey, the author uses the theory of foreign policy which has derivatives in the form of Turkish foreign policy, the concept of discrimination, and the concept of ethnicity. The research method used in this research is a qualitative research method with a descriptive-analytic model. The result of this research is that the Chinese government has committed human rights violations against ethnic Uighurs as evidenced by the findings in the form of Chinese government policies towards ethnic Uighur minorities, restrictions on access to education and religion, and the construction of Uighur concentration camps. The historical, cultural, and religious ties between the Proto Turks and the Uighurs became the basis for Turkey to respond to China's discriminatory actions. To overcome these problems, the Turkish government responded in the form of verbal responses and non-verbal responses in addressing the problems that occurred to the Uighurs in Xinjiang.

Keywords: Response; Turkish; Discriminatory; Uighur Ethnicity

\begin{abstract}
Abstrak
Penelitian ini bertujuan untuk menjelaskan respon Turki terhadap tindakan diskriminatif yang dilakukan oleh pemerintah Cina kepada etnis uighur di Xinjiang pada tahun 2009 - 2015. Tindakan diskriminatif terjadi karena adanya kompleksitas budaya di sebuah negara, salah satunya Cina yang telah melakukan tindakan diskriminatif kepada etnis Uighur. Untuk mengetahui respon yang diberikan Turki, penulis menggunakan teori kebijakan luar negeri yang memiliki turunan berupa politik luar negeri Turki, konsep diskriminasi, dan konsep etnis. Adapun metode penelitian yang digunakan dalam penelitian ini adalah metode penelitian kualitatif dengan model analitik deskriptif. Hasil dari penelitian ini adalah pemerintah Cina telah melakukan pelanggaran hak asasi manusia terhadap etnis Uighur terbukti dengan adanya temuan-temuan berupa kebijakan-kebijakan pemerintah Cina kepada etnis Uighur minoritas, pembatasan akses pendidikan dan agama serta pembangunan kamp konsentrasi uighur. Adanya keterikatan baik secara historis budaya maupun agama antara etnis Proto Turki dengan etnis Uighur menjadi dasar Turki memberikan respon terhadap tindakan diskriminatif Cina. Untuk mengatasi permasalahan tersebut, pemerintah Turki memberikan respon berupa respon verbal
\end{abstract}


dan respon non-verbal dalam menyikapi permasalahan yang terjadi kepada etnis Uighur di Xinjiang.

Kata kunci: Respon; Turki; Diskriminatif; Etnis Uighur.

\section{Pendahuluan}

Hak asasi manusia (HAM) merupakan hak yang sudah melekat pada setiap individu manusia bahwa manusia memiliki kesamaan dan kebebasan tanpa adanya perbedaan baik dari segi agama, ras, pandangan politik, jenis kelamin maupun golongan. Pelanggaran hak asasi manusia adalah perilaku menyimpang yang merugikan hak-hak seseorang biasanya dilakukan oleh individu, kelompok bahkan negara. International Criminal Court (ICC) mengkategorikan terdapat 4 bentuk pelanggaran HAM berat yaitu kejahatan kemanusiaan, kejahatan perang, tindakan agresi dan tindakan genosida (UN Office of the Hights Commisioner for Human Rights). Tindakan genosida adalah sebuah bentuk pemusnahan suatu kelompok atau etnis yang dilakukan secara besar-besaran dan sistematis yang bertujuan untuk menghilangkan keberadaan etnis dari sebuah negara. Tindakan diskriminatif yang terjadi kepada etnis Uighur di Xinjiang merupakan bentuk dari pelanggaran hak asasi manusia dilakukan oleh negara kepada warga negaranya.

Keberadaan sebuah etnis di dalam negara merupakan bentuk dari adanya karateristik sosial budaya sehingga sudah menjadi tanggung jawab negara untuk memberikan perlindungan kepada warga negaranya dari tindakan diskriminatif. Namun kenyataannya, saat ini negara justru menjadi pelaku utama yang melakukan tindakan diskriminasi kepada warga negara minoritas atau etnis minoritas karena adanya perbedaan budaya yang mendasar. Adanya kesenjangan sosial, ekonomi, pendidikan, budaya bahkan agama menjadi pelopor terjadinya tindakan diskriminasi yang dilakukan negara kepada warga negaranya. Oleh karena itu negara sudah dianggap sebagai pelaku pelanggaran HAM berat yang menuju pada impunitas.

Tindakan diskriminatif dapat terjadi karena adanya konflik internal yang pada akhirnya menjadi pemicu adanya tindakan-tindakan diskriminasi negara, salah satunya Cina. Seperti yang diketahui bahwa Cina merupakan negara dengan kekuatan ekonomi yang baik saat ini, tetapi tidak terlepas dari konflik internal negaranya yang dapat menghambat pertumbuhan dari negara Cina tersebut. Konflik internal ini dapat berkembang dari yang awalnya berupa konflik intra-state dapat menjadi konflik interstate (Karisma, 2016). Konflik internal yang berkembang akan mempengaruhi stabilitas keamanan tidak hanya untuk Cina tetapi juga untuk negara tetangga yang secara geopolitiknya berdekatan. Konflik yang terjadi pada etnis Uighur di Xinjiang termasuk ke dalam Low Intensity Conflict (LIC) dimana terdapat peran elit politik yang menargetkan etnis minoritas demi mencapai kepentingan politik sesuai dengan ideologi negaranya tersebut.

Etnis Uighur atau Xinjiang Uighur Autonomous Region (XUAR) adalah etnis minoritas di Cina yang beragama Islam dengan aliran Sunni. Etnis Uighur merupakan keturunan dari etnis Proto Turki dimana terdapat kesamaan bahasa dan budaya, 
sehingga mengganggap bahasa Cina adalah bahasa asing. Etnis Uighur menempati wilayah Xinjiang yang berlokasi di sebelah barat Cina yang berbatasan langsung dengan negara Kazakhstan dan Kyrgistan (Hidayat, 2013)

Pada tahun 1940 (The Uyghur American Association) Turkestan Timur adalah sebuah negara merdeka yang memiliki geografi beragam seperti pegunungan, gurun, sungai dan sumber daya alam yang melimpah. Dahulu kala Turkestan Timur ditempati oleh etnis yang berasal dari Asia Tengah seperti etnis Uighur, etnis keturunan Kazakhstan, Kyrgistan, Uzbekistan dan Tajikistan. Karena letaknya yang strategis sehingga membuat wilayah ini menjadi tempat yang sangat strategis bagi pertukaran ekonomi maupun budaya. Kemudian pada tahun 1876 terjadi invasi yang dilakukan oleh Dinasti Qing Manchu Cina untuk menaklukkan wilayah Xinjiang yang pada akhirnya Xinjiang menjadi bagian dari wilayah Cina. Semenjak bergabungnya wilayah Turkestan Timur atau yang saat ini dikenal dengan nama Xinjiang, sistem pemerintahan berubah menjadi komunis dan adanya keterbatasan akibat perbedaan budaya yang ada. Etnis Uighur harus bertahan hidup secara budaya dari derasnya arus globalisasi karena perbedaan etnis.

Xinjiang dianggap sebagai salah satu kawasan otonomi di Cina di bawah pemerintahan komunis Cina. Provinsi Xinjiang membangun perekonomian dengan sangat pesat karena terbantu dari sektor infrastruktur. Sejak masuknya wilayah Xinjiang ke Cina, pemerintah Cina berfokus untuk melakukan population balance atau keseimbangan populasi antara etnis Uighur dan etnis Han. Dikarenakan adanya program keseimbangan populasi dan sulitnya menerima heterogenitas budaya, pemerintah Cina melakukan berbagai tindakan diskriminatif.

Etnis adalah sekelompok masyarakat yang memiliki persamaan secara karakteristik kesamaan atas identitas sosial, identitas kebudayaan, bahasa bahkan agama. Etnis merupakan bentuk dari identifikasi sosial yang terjadi di masyarakat. Aspek lainnya yang dapat dikategorikan sebagai pengelompokkan etnis dapat dilihat dari kilas balik sejarah keberadaan etnis tersebut, kilas balik nenek moyang, simbolsimbol budaya, bahasa khas yang digunakan hingga tradisi. Selain itu kesamaan agama, kesamaan biologis hingga faktor historis menyebabkan adanya ikatan etnisitas yang kuat. Ikatan etnisitas inilah yang mampu menyatukan orang dari berbagai belahan dunia sekalipun apabila memiliki historis etnis yang sama, maka sudah sewajarnya untuk memberikan dukungan dan bantuan terhadap etnis yang dilanggar hak asasinya. Hal ini yang terjadi terhadap etnis Proto Turki yang memiliki keserumpunan dengan etnis Uighur di Xinjiang Cina.

Dalam penelitian ini, etnis Proto Turki memiliki kesamaan historis sosial budaya dan agama dengan etnis Uighur di Xinjiang. Ikatan etnisitas yang melatarbelakangi adanya keterkaitan antara pemerintah Turki dengan etnis Uighur. Sehingga memunculkan reaksi berupa respon yang diberikan secara resmi oleh pemerintah Turki kepada pemerintah Cina. Hal ini sejalan dengan kebijakan luar negeri Turki yang menganut sistem aktif dan humanis. Kebijakan luar negeri (Amstutz, 2013) merupakan sebuah konsep yang terdiri dari pemikiran-pemikiran untuk mencapai sebuah 
kepentingan nasional negara. Kebijakan luar negeri bersifat dinamis untuk mengikuti perkembangan ekonomi sosial politik dunia.

Kebijakan luar negeri Turki mengalami perkembangan yang sangat signifikan. Pada awalnya, Turki merupakan negara yang menganut sistem pemerintahan sekuler pada kepemimpinan Mustafa Kemal Ataturk. Pada masa kepemimpinan Mustafa Kemal, agama menjadi poros utama yang memiliki ruang khusus di bawah pengaruh negara. Selain itu, militer menjadi kekuatan utama di dalam pemerintahan yang kemudian dipercaya untuk menjaga dan melanjutkan enam (6) prinsip Kemalisme yang pada saat itu berkuasa. 6 prinsip kemalisme diantaranya: nasionalisme, sekularisme, popular sovereignty atau populisme, etatisme dan revolusionisme (Alfian, 2018)

Setelah selesainya masa pemerintahan sekulerisme Turki, dan keinginan untuk bergabung dengan Uni Eropa yang diharuskan negara anggotanya menganut sistem pemerintahan demokrasi membuat Turki beralih menjadi negara yang demokrasi. Para politisi Islam dengan ideologi Islamisme membentuk partai AKP (Adalet Ve Kalkinma Partisi), Partai Keadilan dan Pembangunan yang mendapatkan apresiasi dari masyarakat Turki. Semenjak berkuasanya AKP dan Erdogan, perkembangan Turki terlihat sangat pesat. Seperti yang sudah dijelaskan sebelumnya, kebijakan luar negeri sebuah negara dipengaruhi faktor internal dan eksternal, begitupun Turki (Juanidi, 2016)

Kebijakan luar negeri Turki tidak terlepas dari adanya kepentingan nasional Turki sendiri. Keberpihakan Turki untuk membantu negara-negara Islam yang berkonflik membuktikan bahwa ideologi Islamisme masih sangat erat kaitannya dengan Turki. Hal ini membuat Turki menjadi negara tujuan para aktivis Islam di negara berkonflik untuk membentuk sebuah gerakan kerja sama. Ini merupakan salah satu alasan mengapa Turki ingin membantu melepaskan penderitaan yang diterima oleh etnis Uighur di Xinjiang Cina.

Kebijakan luar negeri Turki yang aktif yakni turut berperan aktif dalam menjaga stabilitas dan keamanan kawasan, penguatan hubungan kerja sama strategis, perluasan jaringan investasi dan perdagangan serta keamanan energi dan peningkatan diplomasi "soft power" Turki. Sedangkan kebijakan luar negeri humanis yang dimaksud yakni memberikan bantuan terhadap negara yang terlibat kasus hak asasi manusia, menampung pengungsi Suriah dan etnis Uighur, memperkuat kerja sama dalam memberantas terorisme, bekerja sama dengan negara lain dan bergabung di dalam organisasi internasional. Sebagai catatan penting dari beberapa hasil penelitian sebelumnya diungkapkan (Laylia, 2018) Tekanan yang dilakukan oleh pemerintah Tiongkok terhadap etnis Uighur dan banyaknya korban yang jatuh dalam kerusuhan memunculkan reaksi dari public dan pemerintah Turki. Bahkan tekanan yang dilakukan oleh pemerintah Cina terhadap etnis Uyghur dan banyaknyakorban yang jatuh dalam kerusuhan memunculkan reaksi dari publik dan pemerintah Turki (Felicia Amelia, n.d.). Alasan penelitian ini dilakukan untuk mengkaji sejauhmana penyebab konflik kedua negara dilihat dari persfektif kepentingan negara. Adapun tujuan penelitian ini mengaitkan faktor-faktor afektif yang mempengaruhi sikap Turki terhadap etnis Uyghur 
yang mendiami wilayah Xinjiang dan hubungan Turki serta hubungannya dengan Cina. Sehingga manfaat penelitian ini adalah untuk memberikan sumbangan, pemikiran dan memberikan konsep-konsep, teori-teori terhadap studi Hubungan Internasional, serta sebagai referensi atau sumber dan bahan kajian tambahan bagi pihak lain yang ingin memperluas kajian ilmu Hubungan Internasional.

\section{Metode Penelitian}

Pendekatan metode kualitatif dalam tulisan ini dilakukan untuk mengeksplorasi berbagai persfektif permasalahan sosial (Creswell, n.d.) dengan data tracing yang diigunakan untuk mendukung analisis fenomena masalah melalui temuan fakta-fakta berita (Kim et al., 2011). Penelitian tracing melewati beberapa langkah-langkah metodologi seperti pencarian data sesuai dengan topik penelitian, pengumpulan data, pengolahan data dan penginterpretasian data dengan metode ilmiah. Hasil analisis yang sudah disusun sesuai dengan metode alamiah kemudian diolah menjadi sebuah laporan atau karya tulis ilmiah. Penelitian ini bertujuan untuk memahami fenomena-fenomena yang terjadi dengan cara yang sistematis. Teknik pengumpulan data yang digunakan dengan library research atau studi kepustakaan seperti buku, jurnal ilmiah, artikel ilmiah, penelitian terdahulu yang memiliki relevansi data dan portal berita.

\section{Hasil dan Pembahasan}

Pendapat dari Brown, mengidentifikasikan empat faktor sebagai penyebab konflik internal, diantaranya, pertama, structural factors misalnya karena lemahnya legitimasi politik, kedua, political factors misalnya diskriminasi politik, civic nationalism, dan ethnic nationalism, ketiga, economic/social factors yaitu menyangkut masalah ekonomi ataupun diskriminasi sistem ekonomi, keempat, cultural/perceptual factors misalnya adanya diskriminasi budaya atau mengucilkan kaum minoritas.

Masalah konflik internal ini menjadi sangat penting karena pada titik tertentu konflik internal yang bisanya bersifat intra state dapat berkembang menjadi konflik inter state. Dalam konteks Cina, konflik intra state yang sulit diselesaikan cenderung akan mengundang keterlibatan actor diluar negara yaitu negara tetangga China seperti Asia Selatan dan Tengah. Beberapa isu yang memicu konflik dengan negara tetangga misalnya yang berkaitan dengan isu penyelundupan senjata maupun masalah pengungsi. Hal tersebut akhirnya dapat merusak hubungan antar negara yang bertetangga. Selain itu, konflik internal Cina yang bisa berkembang menjadi interstate juga turut menyebabkan kerentanan instability terutama bagi kawasan yang secara geopolitik berdekatan, seperti Asia Tenggara dan khususnya Indonesia. Alhasil dalam penelitian ini ditermukan manfaat informasi baru jikalau konflik internal di Cina sebetulnya bukan merupakan konflik yang cukup besar di level konflik etnis duia. 


\section{A. Bentuk-Bentuk Tindakan Diskriminatif Pemerintah Cina Kepada Etnis Uighur di Xinjiang}

1. Program Migrasi etnis Han

Pada 1950-an pemerintah Cina membuat program migrasi etnis Han ke wilayah Xinjiang, etnis Han yang berasal dari Cina bagian Timur kemudian mendapatkan pekerjaan yang diberikan kekuasaan tinggi (Human Rights in China). Sedangkan etnis Uighur yang sudah lama tinggal di Xinjiang hanya menjadi penduduk kelas buruh (pekerja kasar) yang mendapat penghasilan minim dan penghidupan yang tidak layak. Program migrasi ini bukan hanya memindahkan penduduk saja, tetapi juga mengambil alih posisi di pemerintahan. Sehingga hanya keturunan etnis Han yang dapat bekerja di bagian pemerintahan. Hal ini sejalan dengan prinsip monokultural Cina yang hanya mengizinkan warga negara yang fasih berbahasa Cina yang dapat bekerja di bagian pemerintahan.

2. Kebijakan monokultural Cina

Kebijakan monokultural adalah kebijakan dimana di dalam sebuah negara hanya diizinkan memiliki budaya, bahasa dan identitas yang sama. Monokultural pada prinsipnya tidak menerima adanya perbedaan dan keberagaman budaya atau bahasa. Monokultural dimaksudkan untuk meningkatkan rasa nasionalisme terhadap negara. Kebijakan monokultural juga yang membuat adanya perbedaan-perbedaan spesifik antara etnis Uighur dengan etnis lainnya. Tidak dapat menerima heterogenitas budaya, membuat pemerintah Cina terus melakukan tindak diskriminasi kepada etnis Uighur.

3. Pelarangan kegiatan beragama

Pemerintah Cina membuat peraturan lanjutan yang diresmikan pada 23 Agustus 1999 yang isinya jelas tentang pembatasan kegiatan beragama, memberikan sanksi bagi warga yang ketahuan melakukan ibadah, melarang kegiatan beribadah seperti salat atau puasa, menghancurkan beberapa bangunan masjid di Xinjiang dan menonaktifkan masjid-masjid dari fungsinya. Dilakukan alih fungsi masjid yang seharusnya digunakan untuk beribadah, saat ini dikelola pemerintah dan dijadikan museum sejarah. Walaupun dijadikan museum, baik warga maupun turis dilarang memotret di sekitar masjid.

4. Pengendalian kelahiran atau birth control

Kebijakan satu anak melalui kebijakan satu anak atau yang dinamakan one child policy, hal ini terdapat pada Peraturan Keluarga Berencana dan mulai diberlakukan sejak tahun 1980. Kebijakan satu anak mewajibkan setiap keluarga hanya memiliki satu anak saja, apabila melanggar maka akan diberikan sanksi berupa aborsi paksa, sterilisasi dari kehamilan, pemutusan hubungan kerja dan denda. Kontrol atas kelahiran ini tentu saja berakibat besar terhadap keberlangsungan hidup masyarakat khususnya etnis Uighur, dimana dilarang untuk meregenerasi keturunan Uighur yang akan menyebabkan semakin terpojok dan minoritas di Xinjiang. 
5. Pembatasan kurikulum pendidikan

Pembatasan yang dilakukan bertujuan untuk menghilangkan nilai dan budaya Turki yang terdapat di dalam sejarah etnis Uighur. Sehingga etnis Uighur tidak dapat mempelajari nilai budaya dan bahasa leluhurnya dan berfokus pada nilai-nilai komunisme Cina. Di dalam merealisasikannya, pemerintah Cina mewajibkan menggunakan bahasa Cina melarang adanya pembelajaran yang berkaitan dengan bahasa Uighur, bahasa Turki, sejarah etnis Uighur dan budaya-budaya Uighur.

6. Program Pengumpulan Deoxyribo Nucleic Acid (DNA)

Program pengumpulan DNA (Wee, 2019) adalah program yang digalakkan pemerintah Cina untuk mengumpulkan hasil tes DNA seluruh warga Uighur yang setidaknya terdapat dua belas juta jiwa etnis Uighur di Xinjiang. Tes kesehatan ini wajib dilakukan oleh seluruh warga etnis Uighur tanpa terkecuali. Rangkaian tes yang dilakukan dengan mengumpulkan sampel darah, melakukan pemindaian wajah, melakukan perekaman suara, melakukan pengumpulan sampel sidik jari dan perekaman iris mata. Sampel DNA yang diperoleh kemudian diteliti dan didata di kepolisian Cina untuk menghubungkannya ke database kependudukan Xinjiang. Program Pengumpulan DNA ini dapat digunakan oleh pemerintah Cina untuk mengontrol segala aktivitas yang dilakukan etnis Uighur di Xinjiang hanya melalui smartphone.

7. Kamp konsentrasi Uighur

Kamp konsentrasi adalah kamp khusus yang berada di dekat Kota Dabancheng, Bagian Barat Cina. Pada tahun 2014, Pemerintah Cina membuat Kampanye Strike Hard dengan tujuan untuk melawan aksi terorisme di Xinjiang. Kampanye ini menargetkan orang-orang yang tinggal di Xinjiang, tidak terkecuali etnis Uighur karena dianggap sebagai "ancaman" dan dikhawatirkan akan melakukan aksi-aksi yang merugikan dan mengancam keamanan Cina. Aksi penangkapan dilakukan secara resmi oleh pemerintah Cina dan menahannya di kamp konsentrasi (Watch, 2015)

Para warga yang ditahan di dalam kamp konsentrasi diwajibkan untuk berlari dan melakukan push-up selama kurang lebih 12 jam. Selain itu, etnis yang ditahan juga diwajibkan untuk bekerja menjadi buruh pabrik di pabrik tekstil yang berada di dalam komplek kamp tersebut. Tindakan pelanggaran lainnya berupa melarang seluruh kegiatan beragama di dalam kamp, melarang penggunaan hijab bagi wanita, melarang membaca kitab suci dan dipaksa untuk menyanyikan lagu kebangsaan Komunis dan diwajibkan mempelajari nilai-nilai komunisme. Apabila terjadi pelanggaran di dalam kamp, maka akan mendapatkan hukuman berupa penyiksaan yang berujung pada penghilangan nyawa seseorang (International, 2018). 
Beberapa titik kamp konsentrasi di Xinjiang Cina, sebagaimana terlihat dalam gambar berikut:

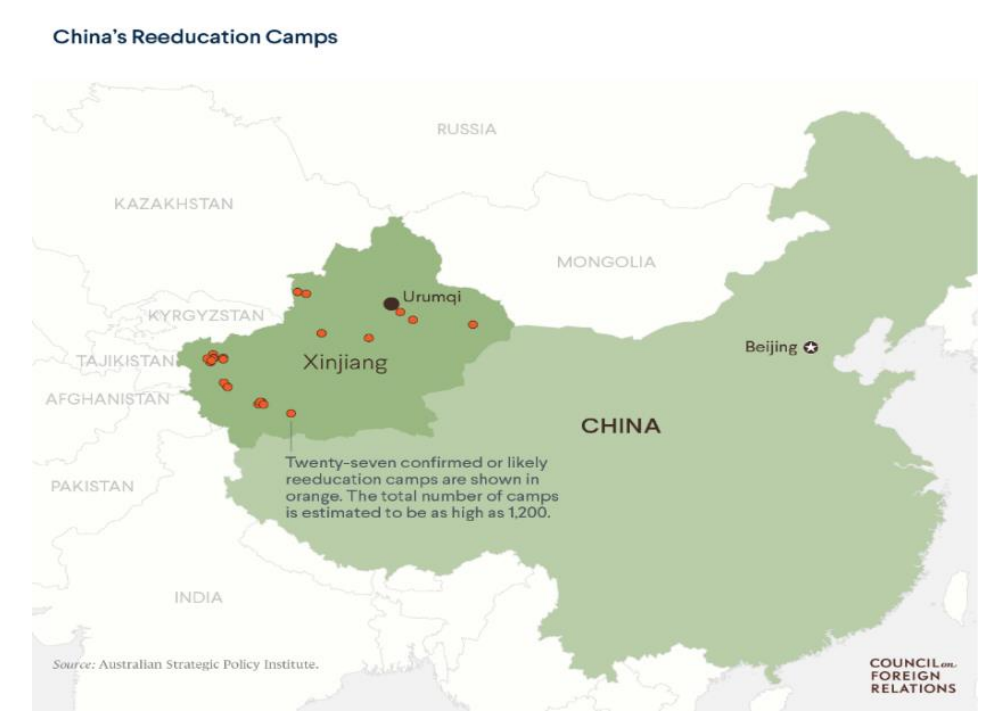

Gambar 1

Peta Kamp Konsentrasi Xinjiang Cina

\section{B. Ikatan Etnisitas Antara Etnis Proto Turki dan Etnis Uighur}

Kesamaan ikatan etnis dapat menjadi salah satu motif utama terjadinya intervensi suatu negara terhadap konflik etnis di negara lain. Tindakan sebuah negara untuk melakukan intervensi maupun diplomasi dapat dilihat dari berbagai faktor dan motivasi negara tersebut. motivasi afektif (affective motivation) adalah motivasi yang dilihat dari adanya kesamaan sejarah, asal muasal, budaya, agama dan bahasa di dalam suatu etnis. Adanya motivasi-motivasi tersebut, dan diperkuat dengan ikatan etnis yang terjalin, sebuah negara tetap akan mempertahankan kepentingan nasionalnya di atas ikatan etnis yang ada. Karena apabila negara melakukan bantuan atau intervensi yang berlebihan, tentu saja akan merugikan negara nya sendiri. Jika negara sudah menganggap bahwa bantuan yang diberikan sudah merugikan negara, maka negara akan secara perlahan-lahan menarik diri dari konflik etnis tersebut untuk tetap menjaga keamanan dari sektor ekonomi maupun politik negaranya.

Jika dilihat dari ikatan etnisitas yang terjadi antara etnis Uighur dengan etnis Proto Turki, maka dapat dikategorikan ke dalam tindakan diplomasi yang dilakukan pemerintah Turki dengan pemerintah Cina. Apabila dilihat dari motivasi yang terjadi, maka dapat dikategorikan di dalam motivasi afektif karena ikatan etnisitas antara etnis Uighur dengan proto Turki dilihat dari persamaan sejarah dan budaya yang ada. Persamaan ikatan etnisitas ini menimbulkan rasa kesamaan primordialisme. Primordialisme adalah sebuah pandangan yang memegang teguh hal-hal yang berkaitan dengan kesamaan asal-usul, adat-istiadat dan rasa 
kepercayaan nenek moyang. Rasa kekeluargaan yang besar karena adanya persamaan bangsa mempererat ikatan etnis Uighur dengan proto Turki.

Etnis Uighur dengan etnis Proto Turki memiliki nilai historis yang sama karena berasal dari keturunan suku yang sama. Hubungan antara kedua etnis memang sudah ada sejak Kerajaan Turki berkuasa di Asia Tengah, dan biasa disebut dengan Klan Turki Uyghur. Klan Turki Uyghur ini adalah sekelompok orang yang memang keturunan dari Turki dan Uighur. Klan Turki Uighur yang merupakan salah satu dari sekian banyak klan yang berasal dari Kerajaan Turki. Klan Turki Uighur ini juga yang membentuk Kekaisaran Uighur dan membawa Kekaisaran tersebut di dalam masa kejayaan.

Klan Turki Uighur umumnya berlokasi di sepanjang jalan sutera seperti Urumqi, Kashgar dan Turfan yang berada di wilayah pegunungan Altaic atau saat ini disebut dengan Xinjiang. (Sloan, 1985) Orang-orang yang berdiam diri di wilayah Xinjiang disebut dengan Qarakhan, percampuran etnis ini yang menjadi etnis Uighur saat ini di Xinjiang Cina.

Dari bahasa yang digunakan, baik etnis Proto Turki maupun etnis Uighur keduanya menggunakan akar bahasa Chaghatay yang memang sudah digunakan di hampir seluruh Asia Tengah pada saat itu. Akar dari Chaghatay tersebut berkembang menjadi bahasa old turkic dengan aksen huruf Arab. Tentu saja budaya yang terdapat di kedua etnis terlihat sangat identik karena memang asal-muasal keduanya berasal dari induk suku yang sama. Mulai dari suara musik, alat musik yang digunakan seperti Dutar, pakaian adat yang memiliki aksen ornamental Turki dan Uighur dengan warna merah ataupun tari-tariannya.

\section{Respon Turki Terhadap Tindakan Diskriminatif Pemerintah Cina Kepada Etnis Uighur}

Hubungan bilateral yang terjalin antara Turki dengan Cina telah berlangsung sejak lama. Walaupun pada tahun 2009, hubungan ini sempat renggang karena kecaman yang diberikan pemerintah Turki terhadap pemerintah Cina yang telah melakukan tindakan diskriminasi kepada etnis Uighur di Xinjiang. Kecaman ini meluas hingga pemerintah Turki memboikot produk-produk Cina yang berada di pasar Turki. Namun hubungan antara Turki dengan Cina membaik pada September 2010 ditandai dengan adanya latihan militer bersama antara kedua negara.

Beberapa hari setelah dilakukannya latihan militer bersama, Perdana Menteri Cina Wen Jiabao melakukan kunjungan resmi di Istanbul Turki untuk membahas beberapa hubungan kerja sama keduanya diantaranya di bidang militer, pertahanan dan ekonomi. Komitmen kedua negara untuk melanjutkan hubungan bilateral ditandai dengan kesepakatan kerja sama yang menetapkan biaya senilai USD \$50 juta pada tahun 2015 dan USD \$100 juta pada tahun 2020. Kunjungan resmi yang dilakukan Perdana Menteri Cina mendapatkan respon baik dengan dilakukannya kunjungan balik dari Kementerian Luar Negeri Turki menuju Cina. Kunjungan ini dilakukan pada 28 Oktober 2010 oleh Menteri Luar Negeri Turki, Ahmet Davutoglu yang menyampaikan rencana penambahan kantor konsulat Turki di Cina 
dan bertujuan untuk meningkatkan kerja sama dan investasi di kedua negara (Kılıç \& Baş, 2010).

Hubungan kerja sama yang terjalin diantara kedua negara semakin terlihat jelas ketika pemerintah Turki membeli rudal jarak jauh untuk menjaga perbatasan Turki dengan Suriah. Kemudian di bidang ekonomi, Turki resmi tergabung di dalam Shanghai Cooperation Organization (SCO) pada 23 Maret 2011 (Mustafa, 2016) SCO merupakan organisasi kerja sama antarpemerintah di wilayah Asia Tengah yang berfokus pada sektor perekonomian, pertahanan dan keamanan untuk meningkatkan keamanan dan stabilitas regional. Kerja sama ekonomi merupakan aspek yang sangat penting dan krusial terhadap kemajuan sebuah negara.

Seiring dengan perkembangan prinsip diplomasi, strategi diplomasi multidimensi yang diterapkan pemerintah Cina dan Turki lebih meluas dengan adanya kerja sama di bidang pertahanan. Walaupun sebenarnya tidak dapat dipisahkan dari bayang-bayang isu kemanusiaan yang terjadi terhadap etnis Uighur di Xinjiang yang merupakan etnis keturunan dari Turki. Selain adanya kerja sama yang dilakukan antara Turki dengan Cina, terdapat respon resmi dari pemerintah Turki diantaranya :

1. Respon Verbal. Respon verbal merupakan bentuk dari respon langsung yang biasanya terdiri dari pernyataan-pernyataan para petinggi negara terkait dengan isu yang terjadi. Terdapat tiga (3) respon verbal yang diberikan Turki kepada Cina yaitu:

a. Pernyataan pemerintah Turki terkait dengan tindakan diskriminatif Cina kepada etnis Uighur

Pernyataan ini diberikan secara resmi oleh Erdogan pada 10 Juli 2009 yang menyebutkan rasa keprihatinan atas diskriminasi yang diterima oleh etnis Uighur di Xinjiang. Di dalam pernyataannya, Erdogan meminta kepada negara-negara Organisasi Konferensi Islam (OKI) untuk membantu melindungi etnis Uighur di Xinjiang, meminta pemerintah Cina untuk menutup kamp konsentrasi karena dianggap melanggar hak asasi manusia. Selain itu juga Erdogan mengancam akan membawa isu etnis Uighur ke dewan HAM PBB.

Melalui pernyataan dari Menteri Luar Negeri Turki, Hami Aksoy pada 9 Februari 2019, menyebutkan bahwa kebijakan asimilasi yang dilakukan pemerintah Cina kepada etnis keturunan Turki Uighur di Xinjiang Cina memalukan bagi kemanusiaan. Hal ini dikarenakan etnis Uighur yang dimasukkan ke dalam kamp-kamp konsentrasi menerima kekerasan baik secara fisik maupun non-fisik. Kegiatan di dalam kamp yang disebut sebagai kamp pendidikan ulang berusaha untuk melakukan doktrin komunisme dan menghilangkan agama dari etnis Uighur. Tidak hanya pemerintah Turki yang mengecam aksi pemerintah Cina kepada etnis Uighur, beberapa aktivis, masyarakat dan media massa juga turut serta di dalam memberikan pernyataan-pernyataan kecaman kepada pemerintah 
Cina. Pernyataan ini bertujuan supaya tidak ada lagi diskriminasi dan tindakan yang melanggar hak asasi manusia yang dilakukan pemerintah Cina kepada etnis Uighur di Xinjiang. Sejak pernyataan resmi ini, hubungan Turki dengan Cina sudah merenggang.

b. Kunjungan Kenegaraan antara Pemerintah Turki dengan Pemerintah Cina

Pada tahun 2009 hubungan Turki dengan Cina sempat memburuk, namun pada September dan Oktober tahun 2010, hubungan kedua negara telah membaik. Hal ini terlihat dari kegiatan latihan militer bersama antara Turki dan Cina yang dilakukan di markas pasukan udara Konya. Hubungan membaik ini juga terlihat dari kunjungan resmi Perdana Menteri Cina, Wen Jiabao yang menyambangi Turki pada 7 Oktober 2010. Beberapa bulan kemudian Kementerian Luar Negeri Turki melakukan kunjungan kenegaraan ke Cina yang diwakili oleh Ahmet Davutoglu. Pertemuan ini fokus membahas tentang rencana Turki untuk menambah kantor konsulat di Cina dan perkembangan investasi antara Cina dengan Turki.

Pada 8 April tahun 2012, terjadi kunjungan kenegaraan yang dilakukan Turki maupun Cina, keduanya menyatakan komitmen untuk saling mendukung kebijakan-kebijakan yang ada di negara tersebut dan Turki berkomitmen untuk membantu menumpas gerakan yang termasuk ke dalam separatisme dan terorisme. Pada tahun 2015, Presiden Erdogan mengunjungi Cina untuk melakukan kunjungan kenegaraan yang membahas tentang hubungan kerja sama ekonomi, politik dan militer antara Turki dengan Cina. Kunjungan ini tidak luput dari pembahasan diskriminasi kepada etnis Uighur di Xinjiang.

Kunjungan ini untuk melanjutkan proyek-proyek kerja sama yang telah terjalin sebelumnya. Hubungan kerja sama antara Turki dan Cina membawa dampak baik bagi perekonomian kedua negara karena menjadi penghubung antara wilayah Asia dengan Eropa. Sejak periode 2009, Turki merupakan salah satu dari negara tujuan impor Cina.

c. Kebijakan Anti-Cina di Turki

Pada tahun 2009, setelah terjadinya demonstrasi besar-besaran yang dilakukan beberapa aktivis Turki dan masyarakat Turki di depan gedung Kedutaan Besar Cina di Ankara Turki, yang menuntut adanya respon dan bantuan Turki untuk membantu etnis Uighur di Xinjiang dari perlakuan diskriminasi Cina. Pemerintah Turki akhirnya membuat kebijakan anti-Cina.

Kebijakan anti-Cina ini awalnya dinyatakan oleh Menteri Perdagangan dan Industri Turki, Nihat Ergun yang memboikot produkproduk yang berasal dari Cina dan melarang masyarakat Turki untuk menggunakan atau membeli barang buatan Cina. Menteri Perdagangan dan Industri juga menyebutkan apabila masyarakat Turki tetap menggunakan dan membeli produk-produk dari Cina maka dianggap tidak menghormati nilai kemanusiaan. 
2. Respon Non-Verbal. Respon non-verbal merupakan bentuk dari respon tidak langsung yang biasanya terdiri dari tindakan-tindakan negara terkait dengan isu yang terjadi. Terdapat tiga (3) respon non-verbal yang diberikan Turki kepada Cina yaitu:

a. Aksi Demonstrasi Masyarakat Turki

Pada Juli 2009, terjadi kerusuhan besar-besaran di Xinjiang yang telah menelan korban jiwa yakni etnis Uighur. Kerusuhan ini terjadi antara etnis Uighur dengan etnis Han di Xinjiang. Kerusuhan didasari oleh aksi militer yang dilakukan pemerintah Cina kepada demonstran yang sedang melakukan demonstrasi di Xinjiang untuk menuntut hak-hak kebebasan dari diskriminasi. Kerusuhan besar ini terdengar hingga Turki, sehingga Perdana Menteri Erdogan saat itu mengecam tindakan pemerintah Cina dan menganggap pemerintah Cina melakukan aksi genosida yang bertujuan untuk menghilangkan etnis Uighur dari Xinjiang. Oleh karena itu, masyarakat Turki merasa tidak terima terhadap perlakuan diskriminasi yang dilakukan pemerintah Cina kepada etnis Uighur dan melakukan aksi demonstrasi di Ankara dan Istanbul.

Aksi demonstrasi ini dibentuk oleh The East Turkestan Education and Solidarity Associaction (ETESA) yang diikuti oleh partai sayap kanan Turki, organisasi pemuda The Great Unity Party (GUP) atau Büyük Birlik Partisi (BBP) dan organisasi Alperen Ocaklari (Laylia, 2018) Massa demonstrasi yang bergabung setidaknya 10.000 orang (Antara News, 2009). Aksi ini didukung oleh masyarakat Turki, para aktivis dari berbagai lembaga dan partai salah satunya Seyit Tumturk kepala Majelis Nasional Turkistan Timur, para tokoh-tokoh agama di Turki dan Uighur, pemerintahan Turki dan media massa di Turki. Media massa yang turut memberikan kecaman dan reaksi keras diantaranya Bugun, Nizli Illicak dan Hurriyet.

b. Pemerintah Turki Menerima Pengungsi Uighur

Kementerian Luar Negeri Turki menyatakan bahwa Turki selalu siap untuk menerima warga Uighur yang ingin mengungsi dari Cina. Pemerintah Turki terus mengupayakan untuk memberikan bantuan-bantuan kepada etnis Uighur. Hal ini tidak menutup kemungkinan adanya bantuan dari LSM atau organisasi yang ingin membantu etnis Uighur di Xinjiang. Pengungsi Uighur mendapatkan akses bebas untuk masuk ke negara Turki, mendapatkan pendidikan yang setara, mendapatkan perhatian khusus dan diberikan bantuan baik secara moral maupun materiil.

Laporan data pada Juli tahun 2015 (Radio Free Asia) menyebutkan terdapat 173 warga etnis Uighur yang telah tiba di Istanbul Turki. Pengungsi ini sampai di Turki pada 30 Juni 2015. Pengungsi ini berasal dari Thailand dimana mereka melakukan pengungsian dan pergi meninggalkan Cina, kemudian pemerintah Turki datang untuk memberikan bantuan kepada etnis 
Uighur. Bantuan ini murni didasari oleh ikatan primordialisme karena memiliki ikatan budaya dan sejarah yang sama.

Seyit Tumturk, Kepala Majelis Nasional Turkistan Timur melaporkan terdapat 173 warga Uighur yang sampai di Istanbul pada hari Selasa. Mayoritas pengungsinya adalah anak-anak dan wanita, terdapat setidaknya 120 anak-anak dan 50 wanita yang mengungsi ke Istanbul. Pengungsi tersebut berasal dari Thailand yang telah berada di Thailand sejak Maret tahun 2014. Sedangkan pada Januari, Turki telah menerima pengungsi lebih dari 500 warga Uighur. Jalur yang dilewati etnis uighur sebagaimana gambar berikut :

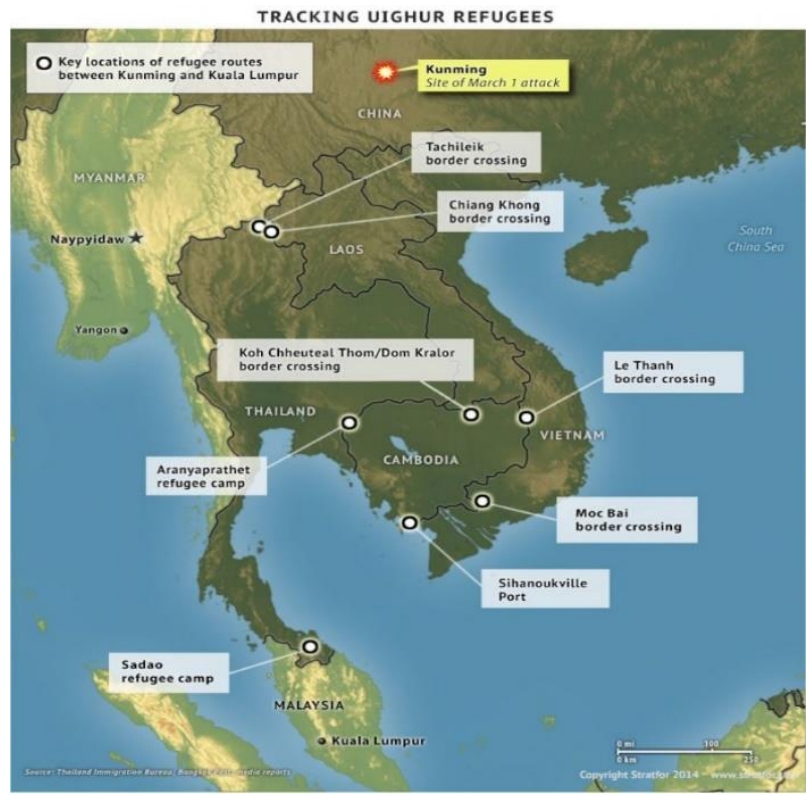

Gambar 2

Jalur Pengungsi Etnis Uighur

c. Latihan Militer Gabungan antara Cina dan Turki

Hubungan antara Turki dengan Cina membaik ditandai dengan adanya latihan militer gabungan yang dilakukan Cina dan Turki. Latihan militer ini merupakan latihan gabungan angkatan udara yang pertama kali melibatkan negara Cina dengan negara anggota North Atlantic Treaty Organization (NATO) yaitu Turki. Latihan militer dilakukan pada 20 September sampai 4 Oktober 2010 di Pangkalan Udara Konya, Anatolia Turki Tengah. Tentara Cina yang terlibat merupakan Chinese People's Liberation Army atau Tentara Pembebasan Rakyat (PLA).

\section{Masa Depan Etnis Uighur di Xinjiang}

Xinjiang merupakan sebuah wilayah di bagian Barat Cina yang saat ini sudah termasuk ke dalam kawasan Otonomi Cina. Alasan Cina ingin menjaga wilayah Xinjiang karena sumber daya alam yang melimpah berada di Xinjiang. Xinjiang merupakan wilayah kedua terbesar yang menyimpan stok batu bara bagi Cina. 
Selain batu bara, perkembangan perekonomian yang sangat pesat juga terjadi di Xinjiang. Lahan yang luas dimanfaatkan untuk membangun perusahaan-perusahaan tekstil di wilayah Xinjiang. Selain itu rempah-rempah yang terdapat di Xinjiang juga sangat melimpah sehingga Cina berusaha untuk menguasai Xinjiang dengan memindahkan etnis Han ke Xinjiang.

Xinjiang juga merupakan jalur perdagangan yang strategis karena menghubungkan wilayah Asia Timur dengan Asia Tengah dan Eropa. Hal ini dinilai sebagai kawasan strategis untuk melakukan perdagangan ekspor impor negara dan akan memberikan dampak yang positif. Memang sejak jaman Kekaisaran Uighur berdiri, Xinjiang merupakan jalur perdagangan yang menghubungkan Cina dengan Persia dan negara-negara Arab lainnya. Hal ini juga yang membawa agama Islam masuk ke dalam Xinjiang khususnya etnis Uighur. Etnis Uighur merupakan etnis keturunan Turki yang sudah lama mendiami wilayah Xinjiang bahkan sejak sebelum Mao Zedong memasukkan Xinjiang ke dalam wilayah Otonomi Cina. Berbagai tindakan diskriminasi diterima dan dirasakan oleh etnis Uighur karena adanya perbedaan antara budaya dan bahasa yang digunakan etnis Uighur dengan etnis lainnya di Cina.

Sistem komunisme Cina membawa perubahan politik yang sangat jelas dengan dibuatnya kebijakan satu Cina dimana diwajibkan untuk menggunakan bahasa Cina, penduduk asli Cina dan tidak dapat menerima keberagaman budaya. Kebijakan satu Cina berdampak pada banyak aspek seperti halnya sistem pemerintahan dan kebijakan-kebijakan kontroversial yang dibuat. Kebijakankebijakan tersebut seperti pengumpulan sampel DNA dari setiap warga Uighur, pemasangan CCTV yang terintegrasi dengan data biometrik, kamp pendidikan ulang yang dibuat seperti penjara dan kebijakan satu Cina. Kebijakan kontroversial yang terus diberlakukan sampai saat ini berupa menikah campur dimana etnis Uighur diwajibkan untuk menikah dengan etnis asli Cina atau etnis Han. Kebijakan menikah campur ini tentu saja menjadi permasalahan baru bagi etnis Uighur karena dipaksa untuk menikah dengan etnis yang tidak sama dengan etnis Uighur.

Berdasarkan analisis yang dilakukan penulis, etnis Uighur nantinya akan bernasib sama seperti isu etnis Rohingya di Myanmar yang dipaksa meninggalkan wilayah Rohingya dan tidak diakui keberadaannya. Perbedaannya disini apabila Rohingya tidak menerima pengakuan sebagai warga dari Myanmar, sedangkan etnis Uighur masih diakui sebagi etnis minoritas yang terdaftar di dalam dokumen pemerintah Cina. Hal ini karena adanya nilai-nilai yang sangat erat dan kental di dalam Cina yang mengedepankan monokulturalisme. Monokulturalisme tidak dapat menerima perbedaan budaya, tidak dapat menerima perbedaan bahasa dan tidak dapat menerima perbedaan nilai-nilai agama. Monokulturalisme tidak dapat menerima heterogenitas budaya dan hanya homogenitas budaya. Pemerintah Cina menganggap Cina hanya milik orang-orang keturunan Cina dan tidak dapat didiami oleh etnis keturunan negara lain. 
Oleh karena itu, apabila terus dilakukan kebijakan-kebijakan kontroversial yang dilakukan pemerintah Cina kepada etnis minoritas khususnya etnis Uighur, maka lama-kelamaan etnis Uighur akan hilang secara permanen. Hal ini dikarenakan tidak adanya regenerasi dari penerus asli Uighur dengan diskriminasidiskriminasi yang terus dilakukan pemerintah Cina kepada etnis Uighur di Xinjiang.

\section{Kesimpulan}

Politik luar negeri Turki telah mengalami beberapa perubahan seiring dengan perkembangan demokratisasi yang terjadi di Turki. Pada awalnya Turki mengedepankan kekuatan militer namun saat ini lebih berfokus pada nilai-nilai demokrasi. Perubahan sikap Turki ditandai dengan peningkatan kerjasama dan kunjungan-kunjungan yang diadakan oleh elit kedua negara. Respon Turki terhadap pelanggaran HAM minoritas muslim Uighur yang dilakukan oleh pemerintah Tiongkok adalah etnisitas antara Uighur dan Turki kurang berpengaruh karena dilandasi oleh pertimbanganpertimbangan lain selain faktor efektif, yaitu faktor instrumental yang dapat dikategorikan dalam politik domestik, keuntungan ekonomi dan kondisi internasional. Faktor efektif merupakan faktor-faktor yang melihat ikatan etnis dalam arti kesamaan sejarah, budaya, dan agama.

Respon Turki ini didasari dengan adanya hubungan kerja sama yang sudah terjalin lama dengan Cina. Respon verbal yang pertama, Perdana Menteri Erdogan pada 10 Juli 2009 meminta Cina untuk menghentikan tindakan diskriminasi kepada etnis Uighur. Kedua, pernyataan resmi dari Menteri Luar Negeri Turki Hami Aksoy pada 9 Februari 2019 yang mengecam kebijakan monokultural Cina karena mengancam keberadaan etnis Uighur dan meminta Cina menghentikan doktrin komunisme. Kemudian pada 8 April 2012 Perdana Menteri Erdogan mengunjungi Cina. Kunjungan kenegaraan ini memang berfokus pada kerja sama antar kedua negara. Ketiga, adanya kebijakan antiCina. Kebijakan anti-Cina mulai diberlakukan saat pemerintah Cina secara terangterangan melakukan diskriminasi kepada etnis Uighur dan membuat pemerintah Turki mengecam aksi tersebut. Kebijakan anti-Cina adalah melarang penggunaan barang yang berasal dari Cina.

Respon non-verbal pertama, aksi demonstrasi yang dilakukan di Istanbul pada 10 Juli 2009, diikuti oleh setidaknya 10.000 massa, aktivis masyarakat Seyit Tumturk, Kepala Majelis Nasional Turkistan Timur, beberapa media massa Turki seperti Bugun, Nizli Illicak dan Hurriyet. Kedua, Turki juga membantu etnis Uighur dengan menerima pengungsi secara sukarela di Turki pada 30 Juni 2015. Etnis Uighur yang ingin mengungsi mendapatkan akses mudah untuk hidup dan menetap di Turki. Berdasarkan laporan Radio Free Asia (RFA) tahun 2015, terdapat 173 etnis Uighur yang sudah ditampung di Turki. Ketiga, Turki dan Cina melakukan latihan militer gabungan pada 4 Oktober 2010 di Pangkalan Udara Konya, Anatolia, Turki Tengah. Latihan militer gabungan ini diikuti oleh Chinese People's Liberation Army atau Tentara Pembebasan Rakyat (PLA). 


\section{BIBLIOGRAFI}

Alfian, M. Alfan. (2018). Militer dan Politik di Turki: Dinamika Politik Pasca-AKP Hingga Gagalnya Kudeta. Bekasi: Penerbit Penjuru Ilmu.

Amstutz, M. R. (2013). International Ethics: Concept, Theories and Cases in Global Politics Fouth Edition. United Kingdom: Rowman \& Littlefield Inc.

Creswell, J. W. (2010.). Research Design Pendekatan kualitatif, kuantitatif, dan Mixed. In Research Design pendekatan Kualitatif, Kuantitatif, dan Mixed ([Edisi Bah). Yogyakarta: Pustaka Pelajar.

Felicia Amelia, S. (2013.). Etnisitas Dan Politik Luar Negeri: Respon Turki Terhadap Penindasan Etnis Uyghur Di Xinjiang. Jurnal Analisis Hubungan Internasional. 2,3. 295-317

Hidayat, Muhammad Nizar. (2013). Diaspora Uyghur dan Hak Sipil di Xinjiang China. Interdependence Journal, 1, 3.

International, Amnesty. (2018). Up to One Million Detained in China's Mass ReEducation Drive. Amnesty International.

Juanidi, Ahmad. (2016). Kebijakan Politik Recep Tayyib Erdogan dan Islamisme Turki Kontemporer. Jurnal Agama Dan Hak Asasi Manusia, 6, 1.

Karisma, Gita. (2016). Konflik Etnis di Xinjiang: Kebijakan Monokultural dan Kepentingan Negara China Terhadap Keutuhan Wilayah. Jurnal Sosiologi, 19, 1.

Kim, Yu Sok, Bogert, Lysander W. J., Immink, Rogier V, Harms, Mark P. M., Colier, Willy N. J. M., \& van Lieshout, Johannes J. (2011). Effects of aging on the cerebrovascular orthostatic response. Neurobiology of Aging, 32(2), 344-353.

K1lıç, Bülent, \& Baş, Erdal. (2010). Complex solutions for the fisher equation and the benjamin-bona-mahony equation.

Laylia, Siti Nida. (2018). Respon Turki Terhadap Pelanggaran HAM Minoritas Muslim Uighur Yang Dilakukan Oleh Pemerintah Tiongkok 2009-2010. Universitas Riau, 5,1 .

Mustafa, Erma Yunita. (2016). Kepentingan Turki Untuk Bergabung Dengan Shanghai Cooperation Organization (SCO). E-Journal Hubungan Internasional Universitas Mulawarman. Kalimantan.

Sloan, Ismail. (1985). History of the Uyghurs, Of Kashgar And Of Greater Turkestan. Anusha.

Watch, Human Rights. (2015). Memberantas Virus Ideologis: Kampanye Represi Tiongkok Terhadap Muslim Xinjiang. HRW Journal. 


\section{Respon Turki terhadap Tindakan Diskriminatif Pemerintah Cina kepada}

Etnis Uighur di Xinjiang (2009-2015)

Wee, Sui Lee. (2019). China Uses DNA to Track Its People, With The Help of American Expertise. New York Times. 